\title{
ANALISIS PRAGMATIS PADA BERITA ACARA PEMERIKSAAN (BAP) KASUS PEMBUNUHAN DI SURABAYA
}

\author{
Mimas Ardhianti \\ Universitas PGRI Adi Buana Surabaya \\ mimasardhianti@unipasby.ac.id
}

\begin{abstract}
ABSTRAK
Penelitian ini bertujuan untuk mendeskripsikan analisis pragmatis pada Berita Acara Pemeriksaan (BAP) kasus pembunuhan di Surabaya. Kajian pragmatik ini mengacu pada tindak tutur dan implikatur pada BAP kasus pembunuhan di Surabaya. Penelitian menggunakan penelitian deskriptif kualitatif.Penelitian deskriptif kualitatif dilakukan sebagai proses penelisikan dan eksplorasi permasalahan sosial.Data dalam penelitian ini berupa kata-kata kata-kata, frasa, kalimat, dan paragraf yang ditemukan dalam BAP. Sumber data dalam penelitian ini adalah Berita Acara Pemeriksaan (BAP) kasus pembunuhan tahun 2015 di Polrestabes Surabaya. Hasil analisis diketahui data yangmengandung tindak tutur dan implikatur ditemukan di dalam Berita Acara Pemeriksaan (BAP) kasus pembunuhan. Jenis tindak tutur pada berita acara pemeriksaan dalam kasus pembunuhanditemukan tindak tutur lokusi, ilokusi, perlukosi, dan implikatur. Rincian tindak tutur dalam Berita Acara Pemeriksaan dalam kasus pembunuhan ditemukan dua puluh tuturan diantaranya, tiga tindak tutur lokusi, tindak tutur ilokusi fungsi representatif tiga tuturan, fungsi direktif dua tuturan, fungsi deklarasi tiga tuturan, tindak tutur perlokusi tiga tuturan sedangkan tindak tutur ilokusi fungsi ekspresif tidak ditemukan pada Berita Acara Pemeriksaan (BAP) dalam kasus pembunuhan karena dalam tuturannya tersebut tidak ada yang mengandung suatu bentuk evaluasi tentang hal yang diujarkannya. Sedangkan implikatur percakapan pada Berita Acara Pemeriksaan (BAP) dalam kasus pembunuhan ditemukan enam tuturan diantaranya, tiga tuturan implikaturcancellability dan tiga tuturan implikatur nondetachability.
\end{abstract}

Kata Kunci: Berita Acara Pemeriksaan (BAP), kasus pembunuhan, pragmatis

ABSTRACT

This study aims to describe the pragmatic analysis in the Police Investigation Report (BAP) of murder cases in Surabaya. This pragmatic study refers to the speech acts and implicatures found in the murder cases in Surabaya. The study is a qualitative descriptive one. Qualitative research is done as a process of investigation and exploration of social problems. The data in this study are words, phrases, sentences, and paragraphs found in BAP. The source of data in this study are BAP of murder cases of 2015 in Surabaya Police distric. The results of the analysis are known data containing speech acts and implicatures found in the BAP of murder cases. The types of speech acts in the BAP of murder case are found in locution, illocutionary, perlukosion, and implicature speech acts. Details of speech acts in the BAP of murder cases reveal twenty speeches, including three locution speech acts, illocutionary speech acts, three speech representative functions, two speech directive functions, three speech declaration functions, three speech perlokusion speech acts, expressive function speech acts were not found in the BAP of murder case because none of the speeches contained a form of evaluation about what was being said. While the conversational implicature in BAP of murder case revealed six utterances including, three utterances of implicature cancellability and three utterances of non-detachability implicature.

Keywords: Investigation Report, murder cas, pragmatic 

Jurnal Belajar Bahasa, ISSN 2502-5864, E-ISSN 2503-0329 Volume 3, No. 2, September 2018

\section{PENDAHULUAN}

Bahasa memiliki fungsi utama sebagai alat komunikasi bagi setiap penggunanya. Pengguna bahasa juga harus menyadari sepenuhnya bahwa dalam konteks apapun bahasa yang digunakan tentu juga harus dapat dimengerti oleh lawan tuturnya. Dengan kata lain, pemahaman yang baik terdapat informasi yang terkandung di dalam peristiwa tutur tertentu akan terwujud manakala penutur dan lawan tutur sama-sama memiliki kemampuan untuk melakukan encode apa saja yang ingin disampaikan dan melakukan decode terhadap bentuk bahasa lawan tuturnya sehingga ia dapat menangkap pesan atau informasi yang diutarakan lawan tuturnya.

Berbicara tentang tindak tutur tentunya tidak lepas dari penutur dan petutur, tetapi juga dari konteks penuturan, pengetahuan tentang status pihak-pihak yang terlibat dalam penuturan, dan maksud tersirat dari penuturan, ini termasuk dalam studi pragmatik. Pragmatik adalah studi tentang makna dalam hubungannya dengan situasi-situasi ujar (speech situations) (Leech, 1993:8).

Oleh karena itu, prasyarat yang diperlukan untuk melakukan analisis pragmatik atas tuturan (T), termasuk $T$ yang bermuatan pelanggaran maksimmaksim pada tindak tutur adalah situasi ujaran yang mendukung keberadaan suatuT dalam percakapan. Situasi ujaran meliputi unsur-unsur: (1) penutur ( $n$ ) dan petutur (t); (2) konteks tuturan; (3) tujuan tuturan; (4) tuturan sebagai bentuk tinakan atau aktivitas; (5) tuturan (T) sebagai produk tindak verbal. 1. Penutur (n) dan petutur (t) Konsep penutur dan lawan tutur ini juga mencakup penulis dan pembaca bila tuturan bersangkutan dikomunikasikan dengan media tulisan. Aspek-aspek yang berkaitan dengan penutur dan lawan tutur ini adalah usia, latar belakang sosial ekonomi, jenis kelamin, tingkat keakraban, 2. Konteks tuturan Konteks tuturan penelitian linguistik adalah konteks dalam semua aspek fisik atau setting sosial yang relevan dari tuturan bersangkutan.

Tindak tutur adalah sepenggal tutur yang dihasilkan sebagai bagian interaksi sosial (Austin, 1956). Leech (1993, hal. 4) menyatakan bahwa sebenarnya dalam tindak tutur mempertimbangkan lima aspek situasi tutur yang mencakup: penutur dan mitra tutur, konteks tuturan, tujuan tuturan, tindak tutur sebagai sebuah tindakan/aktivitas dan tuturan sebagai produk tindak verbal.

Tindak tutur atau tindak ujar (speech act) merupakan entitas yang bersifat sentral dalam pragmatik sehingga bersifat pokok di dalam pragmatik. Tindak tutur merupakan dasar bagi analisis topik-topik pragmatik lain seperti praanggapan, perikutan, implikatur percakapan, prinsip kerja sama, dan prinsip kesantunan. Kajian pragmatik yang tidak mendasarkan analisisnya pada tindak tutur bukanlah kajian pragmatik dalam arti yang sebenarnya (Rustono, 1999, hal. 33).

Menurut Chaer tindak tutur merupakan gejala individual yang bersifat psikologis dan keberlangsungan ditentukan oleh kemampuan bahasa penutur dalam menghadapi situasi tertentu. 

Jurnal Belajar Bahasa, ISSN 2502-5864, E-ISSN 2503-0329

Volume 3, No. 2, September 2018

Dalam tndak tutur lebih dilihat pada makna atau arti tindakan dalam tuturannya (Rohmadi, 2004, hal. 29).

Peristiwa tutur (speech event) merupakan gejala sosial dan terdapat interaksi antara penutur dalam situasi dan tempat tertentu, maka tindak tutur lebih cenderung sebagai gejala individual, bersifat psikologis dan ditentukan oleh kemampuan bahasa penutur dalam menghadapi situasi tertentu (Leech, 1993, hal. 39). Jika dalam peristiwa tutur orang menitikberatkan pada tujuan peritiwa, maka dalam tindak tutur orang lebih memperhatikan makna atau arti tindak dalam tuturan itu (Rohmadi, 2004, hal. 30). Searle mengemukakan bahwa secara pragmatis ada tiga jenis tindakan yang dapat diwujudkan oleh seorang penutur yakni tindak lokusi (locutionary act), tindak ilokusi (illocutionary act), dan tindak tutur perlokusi (perlocutionary act) (Rohmadi, 2004, hal. 30). Hal ini senada dengan pendapat Austin yang juga membagi jenis tindak tutur menjadi lokusi, ilokusi, dan perlokusi. Seperti halnya tindak tutur antara penyidik dengan saksi yang disusun dalam sebuah BAP.

Dalam tuturan yang terjalin antara penyidik dengan saksi terdapat implikatur. Tuturan tersebut, mengandung maksud-maksud tertentu yang berbeda dengan struktur bahasa yang digunakan. Dalam kondisi tersebut suatu penggunaan bahasa sering kali memunyai maksudmaksud yang tersembunyi di balik penggunaan bahasa secara struktural. Pada kondisi seperti itulah suatu kajian implikatur percakapan memunyai peran yang tepat untuk mengaji suatu penggunaan bahasa.

Implikatur merupakan salah satu bagian dalam pragmatik. Berkaitan dengan pengertian, berikut beberapa pengertian tentang implikatur yang dikemukakan oleh ahli-ahli bahasa. Istilah implikatur dipakai untuk menerangkan apa yang mungkin diartikan, disarankan, atau dimaksudkan oleh penutur yang berbeda dengan apa yang sebenarnya yang dikatakan oleh penutur (Brown \& Yule, 1996, hal. 31). Pendapat itu bertumpu pada suatu makna yang berbeda dengan makna tuturan secara harfiah.

Terdapat lima ciri-ciri dari implikatur percakapan, yakni 1) dalam keadaan tertentu, implikatur percakapan dapat dibatalkan baik dengan cara eksplisit ataupun dengan cara kontektual (cancellable), 2) ketidakterpisahan implikatur percakapan dengan cara menyatakan sesuatu. Biasanya tidak ada cara lain yang lebih tepat untuk mengatakan sesuatu itu sehingga orang memakai tuturan bermuatan implikatur untuk menyampaikannya (nondetachable), 3) implikatur percakapan mempersyaratkan makna konvensional dari kalimat yang dipakai, tetapi isi implikatur tidak masuk dalam makna konvensional kalimat itu (nonconventional), 4) kebenaran isi implikatur tidak tergantung pada apa yang dikatakan, tetapi dapat diperhitungkan dari bagaimana tindakan mengatakan apa yang dikatakan (calcutable) (Leech, 1993, hal. 40).

Berita Acara Pemeriksaan (BAP) memunyai peranan penting pada tingkat 

Jurnal Belajar Bahasa, ISSN 2502-5864, E-ISSN 2503-0329

Volume 3, No. 2, September 2018

penyidikan karena BAP akan dijadikan acuan di persidangan. Berita acara dibuat pihak kepolisian berisi suatu cerita tentang duduknya suatu kejadian yang ditulis menurut kewajiban jabatan. Pembuatan BAP bersifat wajib, karena terhadap aturan pembuatannya dalam KUHAP pasal 75 yang berbunyi (1) Berita acara dibuat untuk setiap tindakan tentang pemeriksaan tersangka, penangkapan, penahanan, penggeledahan, pemasukan rumah, penyitaan benda, pemeriksaan surat, pemeriksaan saksi, pemeriksaan di tempat kejadian, pelaksanaan penetapan dan putusan pengadilan, pelaksanaan tindakan lain sesuai dengan ketentuan dalam undang-undang ini; (2) Berita acara dibuat oleh pejabat yang bersangkutan dalam melakukan tindakan tersebut pada ayat (1) dan dibuat atas kekuatan sumpah jabatan; (3) Berita acara tersebut selain ditandatangani oleh pejabat tersebut pada ayat (2) ditandatangani pula oleh semua pihak yang terlibat dalam tindakan tersebut pada ayat (1).

BAP adalah bukti tertulis yang dibuat oleh seorang penyidik terhadap suatu perkara dalam memperoleh informasi dari yang diperiksa, untuk dilanjutkan ke tahap kejaksaan serta ke hakim pada saat sidang di pengadilan. Bukti tertulis yang dibuat oleh penyidik atau disebut BAP terdiri atas beberapa lembaran-lembaran tanya jawab antara penyidik dan yang diperiksa dan unsur-unsur pasal yang dikenai pidana. Pembuatan BAP adalah hal terpenting dalam penyidikan suatu perkara pidana, tugas seorang penyidik sangatlah berat dalam mengungkap perkara, karenanya dalam pembuatan BAP seorang penyidik haruslah memiliki banyak pengalaman dan pengetahuan tentang teori-teori hukum pidana dan pasal-pasal dalam KUHP, serta hukum pembuktian yang diatur dalam KUHAP. Penggunaan bahasa pun juga sangat berpengaruh, karena pada penyidikan seseorang yang diperiksa berasal dari berbagai status sosial dan daerah yang berbeda-beda. Penggunaan bahasa yang tepat sangat berpengaruh untuk menjalin komunikasi dengan baik antara penyidik dan yang diperiksa untuk memperoleh informasi yang tepat sesuai dengan perkara tindak pidana.

Penelitian ini akan mengaji lingustik dibidang pragmatik. Kajian pragmatik ini mengacu pada tindak tutur dan implikatur pada BAP kasus pembunuhan. Dengan demikian, diharapkan dapat diperoleh data yang lebih lengkap untuk memberi gambaran tentang tindak tutur dan implikatur pada BAP kasus pembunuhan.

\section{METODE PENELITIAN}

Penelitian ini menggunakan pendekatan deskriptif kualitatif. Sejalan dengan pendapat Creswell, dalam penelitian deksriptif kualitatif sebagai proses penelisikan dan eksplorasi permasalahan sosial. Penelitian deskriptif didasarkan pada 1) mendeskripsikan dan menemukan tidak tutur pada BAP kasus pembunuhan di Surabaya, 2) mendeskripsikan dan menemukan implikatur pada BAP kasus pembunuhan di Surabaya. Data yang muncul berupa kata-kata dalam dokumen BAP kasus pembunuhan di Jawa 
Timur yaitu berupa teks (kata-kata, frasa, kalimat, dan paragraf). Untuk namanama saksi dan korban yang tertulis dalam BAP akan menggunakan inisial karena BAP termasuk dokumen yang bersifat rahasia.Sumber data penelitian ini berupa dokumen Berita Acara Pemeriksaan (BAP) kasus pembunuhan yang terjadi pada tahun 2015 di Polrestabes Surabaya.

Penganalisisan data didasarkan pada masalah penelitian yaitu tindak tutur dan implikatur. Pertama, analisis tindak tutur pada teks kasus pembunuhan di Surabaya akan dianalisis berdasarkan jenis tindak tutur yakni lokusi, ilokusi dan perlokusi.Kedua, analisis implikatur.

\section{PEMBAHASAN}

Tindak tutur dalam BAP kasus pembunuhan di Surabaya terdapat tindak tutur lokusi, tindak tutur ilokusi, perlokusi dan implikatur.

\section{A. Tindak Tutur Lokusi}

Tindak tutur lokusi adalah tindak tutur yang dimaksudkan untuk menyatakan sesuatu tindak mengucapkan sesuatu dengan kata dan makna kalimat sesuai dengan makna kata itu di dalam kamus dan makna kalimat itu menurut kaidah sintaksisnya.

(1) "Saya saat ini dalam keadaan sehat jasmani dan rohani, tidak pernah masuk rumah sakit jiwa". (BAPKrimum Polrestabes Surabaya, 2015).

Tuturan di atas terjadi saat sdr.WID sedang diinterogasi oleh pihak kepolisian yang berkaitan dengan keadaan jasmani dan rohaninya untuk bisa memberikan keterangan lebih lanjut dalam kasus pembunuhan yang telah dilakukan bersama teman-teman lainnya. Dalam tuturannya tersebut sdr.WID menyampaikan suatu maksud kepada lawan tutur dan menggambarkan sejelas-jelasnya bahwa dirinya dalam keadaan sehat baik jasmani maupun rohani dan tidak ada riwayat masuk rumah sakit jiwa.

(2) "Ya, saya saat ini sedang diperiksa sebagai saksi tentang kasus pembunuhan dan siap diperiksa dengan memberikan keterangan yang sebenar-benarnya." (BAP Krimum Polrestabes Surabaya, 2015).

Tuturan di atas terjadi saat sdr.WID sedang diinterogasi oleh pihak kepolisian yang berkaitan dengan pemeriksaan sebagai saksi untuk bisa memberikan keterangan lebih lanjut dalam kasus pembunuhan yang telah dilakukan bersama teman-teman lainnya. Dalam tuturannya tersebut sdr.WID menyampaikan suatu maksud kepada lawan tutur dan menggambarkan sejelas-jelasnya bahwa dirinya siap untuk diperiksa sebagai saksi dalam kasus pembunuhan yang membawa dirinya ikut andil.

(3) "Riwayat kelahiran: saya lahir di Surabaya tanggal 29 April 1973 dari Bapak M (alm) dan ibu SA, saya anak kedua dari lima bersaudara". (BAP Krimum Polrestabes Surabaya, 2015)

Riwayat pendidikan: pendidikan terakhir di SMA Mardi Siwi Tambaksari Surabaya 1994. Riwayat pekerjaan: sebagai sopir freeland Riwayat keluarga: bercerai Riwayat tempat tinggal: di rumah orang tua di Jalan Mulyorejo Utara No. 43 Surabaya. 
Tuturan di atas terjadi saat sdr.WID sedang diinterogasi oleh pihak kepolisian yang berkaitan dengan pemeriksaan sebagai saksi untuk bisa memberikan keterangan lebih lanjut dalam kasus pembunuhan yang telah dilakukan bersama teman-teman lainnya. Dalam tuturannya tersebut sdr.WID menyampaikan suatu maksud kepada lawan tutur dan menggambarkan sejelas-jelasnya mengenai riwayat hidupnya tanpa memengaruhi lawan tutur untuk bertindak.

\section{B. Tindak Tutur llokusi}

\section{1) Tindak Tutur Representatif}

Tindak tutur ilokusi representatif merupakan tindak tutur yang mengikat penuturnya kepada kebenaran atas hal yang diujarkannya dan mengandung maksud tertentu yang memiliki pengaruh kepada lawan tutur. Beberapa data tentang tindak tutur ilokusi representatif sebagai berikut.

(1) "saya jelaskan bahwa pada awalnya saya membututi sdr. BH tersebut bersama dengan sdr. WID dan sdr. JS kemudian sampai dengan sdr. $\mathrm{BH}$ dihilangkan nyawanya saya bersama dengan sdr. WID, sdr. JS, sdr. T, sdr. W (TNI-AL)". (BAP Krimum Polrestabes Surabaya, 2015).

Tuturan di atas terjadi saat sdr.AH sedang diinterogasi oleh pihak kepolisian yang berkaitan dengan pemeriksaan sebagai saksi untuk bisa memberikan keterangan lebih lanjut dalam kasus pembunuhan yang telah dilakukan bersama temanteman lainnya. Dalam tuturannya tersebut sdr.AH menjelaskan kepada lawan tutur bahwa tuturannya tersebut bermaksud memberikan kesaksian kronologis kejadian yang telah dilakukan bersama teman-teman lainnya yang bermula dari tahap membuntuti sdr. BH kemudian berujung pada pembunuhan terhadap korban.

(2) "Bisa saya jelaskan bahwa yang mempunyai rencana adalah sdr. JS dan saya sendiri. (BAP Krimum Polrestabes Surabaya, 2015).

Tuturan di atas terjadi saat sdr. $\mathrm{AH}$ sedang diinterogasi oleh pihak kepolisian yang berkaitan dengan pemeriksaan sebagai saksi untuk bisa memberikan keterangan lebih lanjut dalam kasus pembunuhan yang telah dilakukan bersama teman-teman lainnya. Dalam tuturannya tersebut sdr. AH menjelaskan kepada lawan tutur bahwa tuturannya tersebut bermaksud mengakui telah membuat sebuah rencana bersama sdr.JS dengan membunuh sdr. $\mathrm{BH}$ karena si korban memunyai hutang kepada sdr. $\mathrm{AH}$ yang tidak segera dibayar.

(3) "Selanjutnya pada saat di atas jembatan tersebut kami berlima turun dari mobil dan mengangkat mayat korban dan di buang ke jurang dari atas jembatan dengan kondisi tangan dan kaki terikat serta mata dan mulut di lakban (BAP Krimum Polrestabes Surabaya, 2015).

Tuturan di atas terjadi saat sdr. $\mathrm{AH}$ sedang diinterogasi oleh pihak kepolisian yang berkaitan dengan pemeriksaan sebagai saksi untuk bisa memberikan keterangan lebih lanjut dalam kasus pembunuhan yang telah dilakukan bersama teman-teman lainnya.Dalam tuturannya tersebut sdr. AH menjelaskan kepada lawan tutur bahwa tuturannya 

Jurnal Belajar Bahasa, ISSN 2502-5864, E-ISSN 2503-0329

Volume 3, No. 2, September 2018

tersebut bermaksud memberikan kesaksian kronologis kejadian yang telah dilakukan bersama teman-teman lainnya dengan membuang korban dari atas jembatan, korban dalam kondisi tangan dan kaki terikat serta mata dan mulut dilakban.

\section{2) Tindak Tutur Direktif}

Tindak tutur ilokusi direktif merupakan tindak tutur yang dilakukan penuturnya atas hal diujarkannya dengan mengandung maksud tertentu yang memiiki pengaruh kepada lawan tutur untuk melakukan tindakan yang disebutkan di dalam tuturan itu. Beberapa data tentang tindak tutur ilokusi direktif sebagai berikut.

(1) "Saya tegaskan bahwa saya tidak kenal atau tidak ada hubungan keluarga tapi sebelum terjadi kasus pembunuhan dua minggu sebelumnya saya telah berusaha menyelidiki dan mencari orang yang benama sdr. $\mathrm{BH}$ disuruh oleh Sdr. $A H$ dengan tujuan menagihhutang. (BAP Krimum Polrestabes Surabaya, 2015).

Tuturan di atas terjadi saat sdr.WID sedang diinterogasi oleh pihak kepolisian yang berkaitan dengan pemeriksaan sebagai saksi untuk bisa memberikan keterangan lebih lanjut dalam kasus pembunuhan yang telah dilakukan bersama teman-teman lainnya. Dalam tuturannya tersebut sdr.WID menjelaskan kepada lawan tutur bahwa tuturannya tersebut bermaksud untuk menagih hutang kepada sdr. BH yang bermula memantau dan mencari korban.

(2) "Saya jelaskan bahwa pada akhir November dan awal Desember 2014 disuruh oleh Sdr. AH untuk memantau gerak gerik sdr. BH(BAP Krimum Polrestabes Surabaya, 2015).

Tuturan di atas terjadi saat sdr.WID sedang diinterogasi oleh pihak kepolisian yang berkaitan dengan pemeriksaan sebagai saksi untuk bisa memberikan keterangan lebih lanjut dalam kasus pembunuhan yang telah dilakukan bersama teman-teman lainnya. Dalam tuturannya tersebut sdr.WID menjelaskan kepada lawan tutur bahwa tuturannya tersebut bermaksud dirinya telah disuruh oleh sdr.AH agar memantau setiap gerak gerik dari sdr. $\mathrm{BH}$.

\section{3) Tindak Tutur Deklarasi}

Tindak tutur ilokusi deklarasi merupakan tindak tutur ilokusi yang mengungkapkan suatu pelaksanaan yang mengakibatkan adanya suatu hal (situasi, keadaan, dan sebagainya) yang baru dengan realitis.Beberapa data tentang tindak tutur ilokusi deklarasi sebagai berikut.

(1) "Akibat perbuatan yang dilakukan oleh sdr. AH bin H M, sdri. MR (istri sdr. AH), sdr. WID dan sdr. FbS pihak yang merasa dirugikan adalah keluarga dari korban sdr. BH. (BAP Krimum Polrestabes Surabaya, 2015).

Tuturan di atas terjadi saat sdr. AS telah menyelidiki para saksi-saksi yang terkait dalam kasus pembunuhan kemudian menyimpulkan informasi tersebut sebagai laporan untuk berita acara pemeriksaan mengenai kasus pembunuhan. Dalam tuturannya tersebut sdr. AS menjelaskan kepada lawan tutur bahwa tuturannya tersebut bermaksud memberikan keputusan dalam perkara kasus pembunuhan terhadap sdr. BH yang telah 
Volume 3, No. 2, September 2018

dilakukan oleh sdr. AH, sdri. MR (istri sdr. $A H)$, sdr. RW, dan sdr. F pihak yang merasa dirugikan adalah dari pihak keluarga korban sdr. BH.

(2) "Selanjutnya pada saat di dalam mobil perjalanan menuju trawas tersebut saya mengatakan bahwa saya yang akan mengeksekusi sendiri sdr. BH kemudian pada saat di eksekusi sdr. BH kepalanya saya bungkus dengan menggunakan tas kresek kemudian tas kresek tersebut saya kencangkan sehingga korban sdr. BH kesulitan bernafas dan pada saat korban meronta ronta saya menindih badan korban dan dilakukan selama kurang lebih 10 menit kemudian setelah dipastikan korban tidak bernafas selanjutnya kami sampai di tempat pembuangan atau di atas sebuah jembatan Watu Ondo daerah Pacet". (BAP Krimum Polrestabes Surabaya, 2015).

Tuturan di atas terjadi saat sdr. A sedang diinterogasi oleh pihak kepolisian yang berkaitan dengan pemeriksaan sebagai saksi untuk bisa memberikan keterangan lebih lanjut dalam kasus pembunuhan yang telah dilakukan bersama teman-teman lainnya. Dalam tuturannya tersebut sdr.AH menjelaskan kepada lawan tutur bahwa tuturannya tersebut bermaksud memberikan keputusan dirinya yang akan membunuh sdr. $\mathrm{BH}$ dengan membungkus kepalanya menggunakan tas kresek sampai korban tidak bisa bernafas kemudian membuang jasad korban di jembatan Watu Ondo daerah Pacet.

(3) "Selanjutnya pada saat di dalam mobil perjalanan menuju trawas tersebut $\mathrm{sdr}$. A mengatakan bahwa sdr. A yang akan mengeksekusi sendiri $\mathrm{BH}$ kemudian pada saat di eksekusi BH kepalanya di bungkus dengan tas kresek kemudian oleh sdr. A tas kresek tersebut dikencangkan sehingga korban kesulitan bernafas dan pada saat korban meronta ronta sdr. A menindih badan korban dan dilakukan selama kurang lebih 20 menit kemudian setelah dipastikan korban tidak bernafas selanjutnya kami sampai di tempat pembuangan atau di atas sebuah jembatan Coban Rondo daerah Pacet". (BAP Krimum Polrestabes Surabaya, 2015).

Tuturan di atas terjadi saat sdr.WID sedang diinterogasi oleh pihak kepolisian yang berkaitan dengan pemeriksaan sebagai saksi untuk bisa memberikan keterangan lebih lanjut dalam kasus pembunuhan yang telah dilakukan bersama teman-teman lainnya.Dalam tuturannya tersebut WID menjelaskan kepada lawan tutur bahwa tuturannya tersebut sdr.A memutuskan sendiri untuk mengeksekusi sdr. BH.

\section{4) Tindak Tutur Perlokusi}

Tindak tutur yang pengujaran dimaksudkan untuk memengaruhi mitra tutur dengan daya tuturan itu dapat ditimbulkan oleh penutur secara segaja, dapat pula secara tidak sengaja.

(1) "Banyak pengguna jalan yang mengetahui dan melihat langsung dari atas jembatan canggar sisi batu, meskipun tidak terlihat jelas karena dari jarak yang jauh. (BAP Krimum Polrestabes Surabaya, 2015).

Tuturan di atas terjadi saat sdr. M sedang diinterogasi oleh pihak kepolisian yang berkaitan dengan pemeriksaan sebagai saksi untuk bisa memberikan keterangan lebih lanjut dalam penemuan jasad tidak dikenal terkait kasus 
Jurnal Belajar Bahasa, ISSN 2502-5864, E-ISSN 2503-0329

Volume 3, No. 2, September 2018

pembunuhan. Dalam tuturannya tersebut sdr.M menjelaskan kepada lawan tutur bahwa tuturannya tersebut memberitahukan adanya penemuan mayat di jembatan wisata Watu Ondo memengaruhi pengguna jalan maupun orang yang datang berkunjung ke wisata untuk melihat dari atas jembatan canggar sisi batu.

(2) "Setelah itu T langsung memukul BH bertubi-tubi setelah itu saya juga memukul $\mathrm{BH}$ dan pada saat perkelahian tersebut banyak warga yang datang serta petugas satpam pergudangan tersebut yang kemudian hendak melerainya tetapi warga serta satpam tidak jadi melerai karena $\mathrm{W}$ turun dari mobil dan berteriak "jangan ikut aku" setelah tidak ada perlawan dari $\mathrm{BH}$ kemudian $\mathrm{BH}$ dimasukan ke dalam mobil Toyota Avanza dengan posisi duduk di belakang bangku sopir dan samping saya, $\mathrm{W}$ dan $\mathrm{T}$ duduk di samping BH". (BAP Krimum Polrestabes Surabaya, 2015).

Tuturan di atas terjadi saat sdr.WID sedang diinterogasi oleh pihak kepolisian yang berkaitan dengan pemeriksaan sebagai saksi untuk bisa memberikan keterangan lebih lanjut dalam kasus pembunuhan yang telah dilakukan bersama teman-teman lainnya. Dalam tuturannya tersebut sdr.WID menjelaskan kepada lawan tutur bahwa tuturannya tersebut dapat memengaruhi warga yang mengetahui peristiwa tersebut untuk melerai atau membantu sdr.BH namun warga dicegah oleh sdr.W untuk tidak ikut campur.

(3) "Saya mengetahui setelah diberi informasi oleh pengendara sepeda motor yang tidak saya kenal lalu saya diberitahu lagi oleh PE, pekerjaan penjual tape ketan hitam, alamat dsn. Jatirejo, ds. Centong, kec. Gondang, kab. Mojokerto dengan bilang kepada saya "pak, delok'ane onok mayit nang kali, sampean cek" (pak, tolong dilihat kelihatannya ada mayat di sungai)". (BAP Krimum Polrestabes Surabaya, 2015).

Tuturan di atas terjadi saat sdr. M sedang diinterogasi oleh pihak kepolisian yang berkaitan dengan pemeriksaan sebagai saksi untuk bisa memberikan keterangan lebih lanjut dalam penemuan jasad tidak dikenal terkait kasus pembunuhan. Dalam tuturannya tersebut sdr.M menjelaskan kepada lawan tutur bahwa tuturannya tersebut mendapatkan informasi dari pengendara sepeda motor yang tidak dikenalnya kemudian ia diberitahu lagi dari PE seorang penjual tape hitam sehingga sdr. $M$ terpengaruh untuk melihat kebenaran informasi yang didengarnya bahwa ada jasad ditemukan di sungai.

\section{Implikatur Percakapan \\ 1) Implikatur Cancellability}

Dalam keadaan tertentu, implikatur percakapan dapat dibatalkan baik dengan cara eksplisit ataupun dengan cara kontektual.

(1) "Menurut saya mayat tersebut dibuang ke bawah jembatan bukan pada saat itu (siang hari), melainkan malam hari karena mulai pagi hari sampai sore jalan raya sangat ramai dan lokasi penjual tape ketan hitam tersebut dekat dengan jembatan canggar hanya kurang lebih 10 (sepuluh) meter, apabila ada orang membuang mayat di jembatan pasti terlihat dari tempat penjual ketan hitam tersebut". (BAP Krimum Polrestabes Surabaya, 2015) 
Volume 3, No. 2, September 2018

Tuturan di atas terjadi saat sdr.M sedang diinterogasi oleh pihak kepolisian yang berkaitan dengan pemeriksaan sebagai saksi untuk bisa memberikan keterangan lebih lanjut dalam penemuan jasad tidak dikenal terkait kasus pembunuhan.Dalam tuturannya tersebut sdr. M menjelaskan kepada lawan tutur bahwa tuturannya tersebut menyimpulkan kemungkinannya jasad tidakkenal itu dibuang ketika malam hari bukan siang hari karena dalam keterangannya kondisi jembatan saat pagi sampai sore hari ramai.

(2) "Saya tegaskan bahwa saya tidak kenal atau tidak ada hubungan keluarga tapi sebelum terjadi kasus pembunuhan dua minggu sebelumnya saya telah berusaha menyelidiki dan mencari orang yang benama $\mathrm{BH}$ disuruh oleh Adengan tujuan menagihhutang". (BAP Krimum Polrestabes Surabaya, 2015)

Tuturan di atas terjadi saat sdr.RW sedang diinterogasi oleh pihak kepolisian yang berkaitan dengan pemeriksaan sebagai saksi untuk bisa memberikan keterangan lebih lanjut dalam kasus pembunuhan yang telah dilakukan bersama teman-teman lainnya. Dalam tuturannya tersebut sdr.RW menjelaskan kepada lawan tutur bahwa tuturannya tersebut menyimpulkan ia tidak mengenal dan tidak ada hubungan keluarga dengan korban namun karena ada alasan lain yaitu untuk menagih hutang kepada sdr. BH dan mencari tahu keberadaannya.

(3) "Pada hari senin tanggal 22 Desember 2014 sekitar pukul 09.00 wib saya dijemput oleh $A$ dengan mengendarai mobil Toyota avanza warna hitam nopol w-XXX-xm, didalam mobil sudah ada sdr. T setelah itu saya masuk dengan posisi saya menyetir dan pada saat itu saya menanyakan kepada Atujuannya dan dijawab ke perak ke kantor $\mathrm{BH}$ untuk mengawasi gerak gerik $\mathrm{BH}$ tapi $\mathrm{BH}$ tidak ada karena mobilnya tidak terlihat, setelah dari kantor BH kemudian sekitar pukul 10.00 wib kami pindah ke pertokoan Mutiara Dupak jalan Dupak no 63 Surabaya atau ke tempatnya $\mathrm{BH}$ tapi ditempat tersebut $\mathrm{BH}$ juga tidak ada, selanjutnya kami pindah ke daerah Citraland Lakarsantri Surabaya dengan maksud untuk menunggu $W$ (TNI-AL) (BAP Krimum Polrestabes Surabaya, 2015).

Tuturan di atas terjadi saat sdr.WID sedang diinterogasi oleh pihak kepolisian yang berkaitan dengan pemeriksaan sebagai saksi untuk bisa memberikan keterangan lebih lanjut dalam kasus pembunuhan yang telah dilakukan bersama teman-teman lainnya. Dalam tuturannya tersebut sdr.WID menjelaskan kepada lawan tutur bahwa tuturannya tersebut menyimpulkan tidak menemukan keberadaan sdr.BH di tempat yang memungkinkan ia berada di sana oleh karena itu mereka pindah ke daerah Citraland Lakarsantri Surabaya untuk menunggu sdr. W.

\section{2) Implikatur Nondetachability}

Ketidakterpisahan implikatur percakapan dengan cara menyatakan sesuatu. Biasanya tidak ada cara lain yang lebih tepat untuk mengatakan sesuatu itu, sehingga orang memakai tuturan bermuatan implikatur untuk menyampaikannya

(1) "Menurut saya tidak ada yang mencurigakan. (BAP Krimum Polrestabes Surabaya, 2015) 

Jurnal Belajar Bahasa, ISSN 2502-5864, E-ISSN 2503-0329

Volume 3, No. 2, September 2018

Tuturan di atas terjadi saat sdr.M sedang diinterogasi oleh pihak kepolisian yang berkaitan dengan pemeriksaan sebagai saksi untuk bisa memberikan keterangan lebih lanjut dalam penemuan jasad tidak dikenal terkait kasus pembunuhan.Dalam tuturannya tersebut sdr.M menjelaskan kepada lawan tutur bahwa tuturannya tersebut masih mempertahankan implikatur yang bersangkutan bahwa jasad tersebut dibuang ketika malam hari bukan siang hari sehingga tidak ada jejak yang mencurigakan di sekitar lokasi.

(2) "Benar saya melihat sendiri mayat tersebut saya tidak kenal, dengan ciriciri jenis kelamin laki-laki, bertubuh biasa, kulit kuning langsat, rambut pendek. (BAP Krimum Polrestabes Surabaya, 2015).

Tuturan di atas terjadi saat sdr.M sedang diinterogasi oleh pihak kepolisian yang berkaitan dengan pemeriksaan sebagai saksi untuk bisa memberikan keterangan lebih lanjut dalam penemuan jasad tidak dikenal terkait kasus pembunuhan.Dalam tuturannya tersebut sdr. M menjelaskan kepada lawan tutur bahwa tuturannya tersebut masih mempertahankan implikatur yang bersangkutan bahwa ia telah melihat secara langsung ditemukannya jasad tersebut dengan ciri-ciri yang telah disebutkan.

(3) "Saya jelaskan bahwa suami saya tidak ada masalah dengan saya atau pihak lain (BAP Krimum Polrestabes Surabaya, 2015).

Tuturan di atas terjadi saat sdr.V sedang diinterogasi oleh pihak kepolisian yang berkaitan dengan pemeriksaan sebagai saksi pelapor untuk bisa memberikan keterangan lebih lanjut terkait sdr. BH tidak lain adalah suaminya sendiri. Dalam tuturannya tersebut sdr. V menjelaskan kepada lawan tutur bahwa tuturannya tersebut masih mempertahankan implikatur yang bersangkutan bahwa ia yakin benar jika suaminya tidak ada konflik dengan orang lain.

(4) “Tidak ada barang-barang yang saya temukan di sekitar tempat kejadian peristiwa. (BAP Krimum Polrestabes Surabaya, 2015)

Tuturan di atas terjadi saat sdr.M sedang diinterogasi oleh pihak kepolisian yang berkaitan dengan pemeriksaan sebagai saksi untuk bisa memberikan keterangan lebih lanjut dalam penemuan jasad tidak dikenal terkait kasus pembunuhan. Dalam tuturannya tersebut sdr. Menjelaskan kepada lawan tutur bahwa tuturannya tersebut masih mempertahankan implikatur yang bersangkutan bahwa jasad tersebut dibuang ketika malam hari bukan siang hari sehingga tidak ada jejak yang mencurigakan bahkan barang bukti juga tidak ditemukan di sekitar lokasi.

\section{SIMPULAN}

Ditemukan tindak tutur ilokusi dan perlokusi pada Berita Acara Pemeriksaan (BAP) dalam kasus pembunuhan pada dua puluh tuturan. Implikatur percakapan pada Berita Acara Pemeriksaan (BAP) dalam kasus pembunuhan ditemukan berupa implikatur cancellability dan implikatur nondetachability. 
Jurnal Belajar Bahasa, ISSN 2502-5864, E-ISSN 2503-0329

Volume 3, No. 2, September 2018

\section{DAFTAR RUJUKAN}

Austin, J. L. (1956). How to Do Things with Words. London: Oxford University Press.

Berita Acara Pemeriksaan. (2015).

Polrestabes Surabaya.

Brown, G., \& Yule, G. (1996). Discourse Analysis. Cambridge University Press.

Creswell, J. W. (2010). Metodologi Penelitian Kualitatif: Analisis Data. Jakarta: Rajawali Pers.
Leech, G. (1993). Prinsip-prinsip Pragmatik. (MD, Trans.) Jakarta: Universitas Indonesia.

Rohmadi, M. (2004). Pragmatik: Teori dan Analisis. Yogyakarta: Lingkar Media.

Rustono. (1999). Pokok-pokok Pragmatik. Semarang: IKIP Semarang Press.

Searle, J. R. (1979). Speech Acts: An Essay in the Philosophy of Language. Cambridge University Press.

Tim Viva Justicia. (2016). Kitab UndangUndang Hukum Pidana. Jakarta: Huta Parhapuran. 